\title{
Vertical Transmission of HIV-1 \\ Correlation with Maternal Viral Load and Plasma Levels of CD4 Binding Site Anti-gp120 Antibodies
}

\author{
Yousef F. Khouri, *‡ Kenneth Mclntosh, ${ }^{\ddagger}$ Lisa Cavacini, ${ }^{5}$ Marshall Posner, ${ }^{8}$ Marcello Pagano," Ruth Tuomala," \\ and Wayne A. Marasco* \\ ${ }^{*}$ Dana-Farber Cancer Institute, Division of Human Retrovirology; ${ }^{\ddagger}$ Children's Hospital, Division of Infectious Diseases; ${ }^{8}$ New England \\ Deaconess Hospital, Department of Medicine; and "Harvard School of Public Health, 'Brigham and Women's Hospital, Department of \\ Obstetrics and Gynecology, Harvard Medical School, Boston, Massachusetts 02115
}

\begin{abstract}
Almost all childhood HIV-1 is now acquired through vertical transmission. Identifying factors that affect the rate of transmission may lead to the initiation of specific preventive strategies. In this study, antibody levels against different neutralizing epitopes on the envelope glycoprotein of HIV-1 (gp120) were measured in HIV-1-infected pregnant women that either transmitted HIV-1 to their infants (18 women) or did not (29 women). Differences in levels of antibodies directed against the monomeric gp120 molecule and against the V3 loop region of gp120 were not significantly different between the two groups studied. However, significant differences were observed in the levels of CD4 binding site antibodies, as determined by the ability of diluted maternal plasma to inhibit binding of the CD4 binding site monoclonal antibody F105 (mAb F105) to monomeric gp120. In addition, more nontransmitting mothers had low viral load as defined by having two or more negative HIV-1 viral cultures during pregnancy compared with transmitters. This pilot study suggests that in addition to higher viral load, low levels of CD4 binding site antibodies correlate with increased risk of HIV-1 vertical transmission. Passive immunotherapy with broadly neutralizing CD4 binding site antibodies should be considered as a strategy to reduce this risk. (J. Clin. Invest. 1995. 95:732-737.) Key words: vertical transmission - AIDS - neutralizing antibodies - passive immunotherapy $\bullet$ human anti-gp 120 antibodies
\end{abstract}

\section{Introduction}

The vast majority of childhood HIV-1 in the United States is acquired through vertical transmission. Current estimates indicate that women now represent $12 \%$ of AIDS cases and that $75 \%$ of these women are in the child bearing age (1). HIV-1 infection in women results in the birth of $\sim 1,800$ infected infants in the United States annually (2).

This work was presented in part at the annual meeting of the Infectious Disease Society of America in New Orleans on 16-18 October 1993 and was published in abstract form (1993. Clin. Infect. Dis. 226:568).

Address correspondence to Wayne A. Marasco, M.D., Ph.D., DanaFarber Cancer Institute, Division of Human Retrovirology, Boston, MA 02115. Phone: 617-632-2153; FAX: 617-632-3889.

Received for publication 3 June 1994 and in revised form 21 September 1994.

J. Clin. Invest.

(c) The American Society for Clinical Investigation, Inc.

0021-9738/95/02/0732/06 \$2.00

Volume 95, February 1995, 732-737
Among the most pressing questions in pediatric AIDS are why $15-25 \%$ of infants born to HIV-1 seropositive mothers acquire HIV-1 while the majority of infants do not become infected, and why rates of transmission apparently vary widely among populations on a global basis. Only limited data are currently available on factors affecting HIV-1 vertical transmission. Two recent studies showed that maternal viral load and degree of immune deficiency are associated with greater risk of transmission $(3,4)$. In another study, the level of p24 antigenemia, high CD8 lymphocyte counts, and the presence of placental inflammation correlated with the highest transmission rate (5). Other studies reported a positive correlation between the presence of other sexually transmitted diseases (6) or high maternal IgA levels and vertical transmission (7).

The role that maternal neutralizing antibodies play in vertical transmission continues to be an area of great interest since the protective role of maternal immunity is well established in a number of other congenitally transmitted infections. Most of the neutralizing antibodies generated against HIV-1 are directed against epitopes on the envelope glycoproteins, gp120 and gp41. The humoral immune response to gp120 involves the production of at least two classes of neutralizing antibodies (8). One class is directed against epitopes on the third hypervariable loop of gp120 $(8,9)$. These antibodies appear early after infection, are usually (but not always) strain specific, and may become less important later in infection because of the emergence of escape mutants (10). The presence of these antibodies does not correlate with reduced vertical transmission rate $(11,12)$. Another class of neutralizing antibodies appears later in the course of HIV-1 infection and is more broadly neutralizing. A subset of these antibodies interferes with the binding of gp120 to the CD4 receptor (CD4 binding site antibodies) (13-18). These antibodies neutralize a large array of primary and laboratory strains of HIV-1. Lack of these antibodies is associated with disease progression in adults (19). Their role in HIV-1 vertical transmission, however, has not been explored.

This study was undertaken to identify factors that may affect HIV-1 vertical transmission. Plasma samples from HIV-1-infected women were tested for the levels of total anti-gp120 antibodies and subsets of these antibodies that are directed against the V3 loop and CD4 binding sites. The results of these tests, along with measures of viral load and immune competence, were then correlated with vertical transmission.

\section{Methods}

Maternal plasma samples were obtained through a collaborative investigation with the Women Infants Transmission Study, a multicenter study on HIV-1 vertical transmission. The HIV-1 status of women enrolled was established by the standard serologic assays. Seropositive mothers were classified as transmitters when their infants had two or more posi- 
Table I. Characteristics of HIV-1-seropositive Women at Delivery

\begin{tabular}{lccc}
\hline & Transmitting & \multicolumn{2}{c}{ Nontransmitting women } \\
\cline { 3 - 4 } & $(n=18)$ & $(n=29)$ & $\begin{array}{c}\text { Group B } \\
(n=32)\end{array}$ \\
\hline $\begin{array}{l}\text { Mean age }(y r) \\
\text { Ethnic group }\end{array}$ & 29 & 28 & 30 \\
White, non-Hispanic & $6(33 \%)$ & $11(38 \%)$ & $13(41 \%)$ \\
Black & $8(44 \%)$ & $10(35 \%)$ & $15(47 \%)$ \\
Hispanic & $3(17 \%)$ & $2(7 \%)$ & $3(9 \%)$ \\
Others* & $0(0 \%)$ & $5(17 \%)$ & $0(0 \%)$ \\
NA & $1(6 \%)$ & $1(4 \%)$ & $1(3 \%)$ \\
IVDU & $5(28 \%)$ & $4(14 \%)$ & $8(25 \%)$ \\
Yes & $11(61 \%)$ & $21(72 \%)$ & $11(34 \%)$ \\
No & $2(11 \%)$ & $4(14 \%)$ & $13(41 \%)$ \\
NA & & & $27(22$ tested) \\
Percent CD4 & + & &
\end{tabular}

$N A$, not available; $I V D U$, Intravenous drug use. * American Indian, Asian, or Pacific Islander. Group A consisted of women whose plasma samples were tested for antibody levels and group B consisted of women whose plasma samples were not tested for antibody levels.

tive HIV-1 peripheral blood cultures (20), showed persistent HIV-1 antibodies beyond 18 mo of age, or had clinical AIDS by the Centers for Disease Control criteria (21). Seropositive mothers were classified as nontransmitters when their infants had no signs of infection and had two or more negative cultures both obtained after 1 mo of age and at least one after 6 mo of age, and no positive cultures (20). Most of these infants had also lost maternal antibodies. Plasma samples from heparinized blood of women followed at four Massachusetts hospitals were tested. All plasma samples from transmitting mothers were tested for antibody levels. Half of the nontransmitting mother samples were selected for testing based on their availability. Age, race, use of intravenous drugs during pregnancy, and CD4 count of nontransmitting women who were selected for the study were not different from those of the group who were not selected (Table I). In addition to antibody levels, other clinical and laboratory data were compared between transmitters and those nontransmitters whose plasma was tested. Plasma samples from HIV-1-negative pregnant women were used as controls. Samples were obtained at different time points during pregnancy and/or at delivery and were heat-inactivated for $45 \mathrm{~min}$ at $55^{\circ} \mathrm{C}$ before use. In each ELISA assay (B-F105 competitive inhibition, soluble CD4 blocking, total anti-gp120, and anti-V3 loop), a single dilution of plasma chosen from the linear portion of the dose-response curve was used after preliminary titering experiments were performed to determine the optimal dilution for maximum sensitivity (data not shown). Each sample was tested in triplicate and average levels were calculated. The antibody levels of all available samples collected from each patient at different time points were averaged and then analyzed. The limited number of samples did not allow statistical analysis of antibody levels measured at each trimester of pregnancy between the two groups.

$B-F 105$ competitive inhibition ELISA. A biotinylated form of the broadly neutralizing human monoclonal antibody F105 (B-F105) was produced (19). Specificity of B-F105 binding to the CD4 binding site of gp120 was confirmed by demonstrating that both soluble CD4 and unlabeled F105 inhibit the binding of B-F105 to gp120 (data not shown). Immulon 1 " $U$ " ELISA plates (Dynatech Laboratories Inc., Chantilly, VA) were coated with recombinant monomeric gp120 of the IIIB strain (American Biotechnology, Cambridge, MA) in $100 \mathrm{mM}$ $\mathrm{NaHCO}_{3}, \mathrm{pH} 9.0$, at $100 \mu \mathrm{l} /$ well ( $100 \mathrm{ng} /$ well). Plates were incubated overnight at $4^{\circ} \mathrm{C}$ and washed with TBS (144 mM NaCl, $25 \mathrm{mM}$ Tris, pH 7.5) containing $0.1 \%$ Tween 20 (TBS-T) (Sigma Immunochemicals, St. Louis, MO). Plates were then blocked with $1 \%$ bovine serum albu- min (BSA) (Sigma Immunochemicals) in TBS-T. Plasma samples were diluted at $1: 300$ in $0.005 \%$ BSA in PBS containing $100 \mathrm{ng} / \mathrm{ml}$ of BF105 (the amount required for half-maximum binding [17]) and allowed to incubate overnight at $4^{\circ} \mathrm{C}$. For each ELISA plate containing samples from infected patients, at least three HIV-1-negative human plasma samples (nhp) ${ }^{1}$ were tested to establish a negative baseline. Positive controls were wells containing B-F105 in diluent without human plasma. In this and the subsequent assays, bound antibodies were detected by the addition of alkaline phosphatase-labeled avidin (Vector Labs Inc., Burlingame, CA) followed by the reaction with the substrate $p$-nitrophenylphosphate (Bio Rad Laboratories, Richmond, CA) and spectrophotometric measurement of the reaction at $405 \mathrm{~nm}$. Reaction of all plates was terminated when the absorbance of samples containing HIV-1negative plasma yielded a measurement of 0.5 . Percent inhibition of BF105 binding was determined using the formula: [F105 absorbance ${ }_{\text {nhp }}$ - F105 absorbance HIV sample $/ \mathrm{F} 105$ absorbance $\left._{\text {nhp }}\right] \times 100$. $^{2}$

Soluble CD4 blocking assay. Plates were coated, incubated, washed, and blocked as described above. Because premixing of diluted plasma samples and soluble CD4 resulted in rapid binding of soluble CD4 to gp120, a prebinding blocking assay was established. Plasma samples were diluted at $1: 100$ in $0.005 \%$ BSA in PBS, placed in the wells of the plates, allowed to incubate overnight $\left(4^{\circ} \mathrm{C}\right)(22)$, and then washed with TBS-T. HIV-1-negative human plasma samples were used to establish negative baseline. Recombinant sCD4 (American Biotechnology) at $50 \mathrm{ng} /$ well was added and allowed to incubate for $4 \mathrm{~h}$ at room temperature. Bound SCD4 was detected by the addition of murine monoclonal anti-CD4 antibodies (American Biotechnology) for $1 \mathrm{~h}$. The assay was completed as described above, and percent blocking levels were determined.

Total anti-gp120 assay. Plates were coated with gp120, incubated, washed, and blocked as described. Plasma samples were diluted at 1:500 and allowed to incubate overnight at $4^{\circ} \mathrm{C}$. Bound antibodies were detected by the addition of biotinylated mouse anti-human IgG (Zymed Labs, Inc., South San Francisco, CA). The assay was completed as described above. The reaction was terminated when the absorbance of a positive control yielded a reading of 0.5 at $405 \mathrm{~nm}$.

Anti-V3 loop assay. Plates were coated with $100 \mathrm{ng} /$ well of recombinant V3 loop peptide (consensus sequence of IIIB strain of HIV-1) (American Biotechnology) and allowed to incubate at $4^{\circ} \mathrm{C}$ overnight. Plates were washed and blocked as described. Plasma samples were diluted at 1:500 in 0.005\% BSA in PBS and allowed to incubate overnight at $4^{\circ} \mathrm{C}$. Bound antibodies were detected by the addition of biotinylated mouse anti-human IgG. The analysis was completed as described in the anti-gp120 assay.

Total immunoglobulin levels. Immunoglobulin levels were measured using Beckman Array Nephelometry (23).

$\mathrm{CD}^{+}$lymphocyte count. Maternal $\mathrm{CD} 4^{+}$lymphocyte counts were measured at delivery using FACScan ${ }^{\circledR}$ flow cytometry (Becton Dickinson, Mountain View, CA) (24).

Viral culture. Viral cultures were performed by cocultivating patients PBMCs with PHA-stimulated PBMCs from HIV-1-negative donors as described (25).

Statistical analysis. $\chi$ square, Fisher exact, and $t$ tests assuming unequal variances were used for analysis (26).

\section{Results}

In this retrospective review, antibody levels and other clinical and laboratory data of 18 transmitters and 29 of 61 nontransmitters were analyzed. Samples collected from nine HIV-1-negative pregnant women were used as a negative control. A total of 104 plasma specimens was tested from seropositive mothers

1. Abbreviations used in this paper: nhp, negative human plasma; sCD4, soluble CD4. 

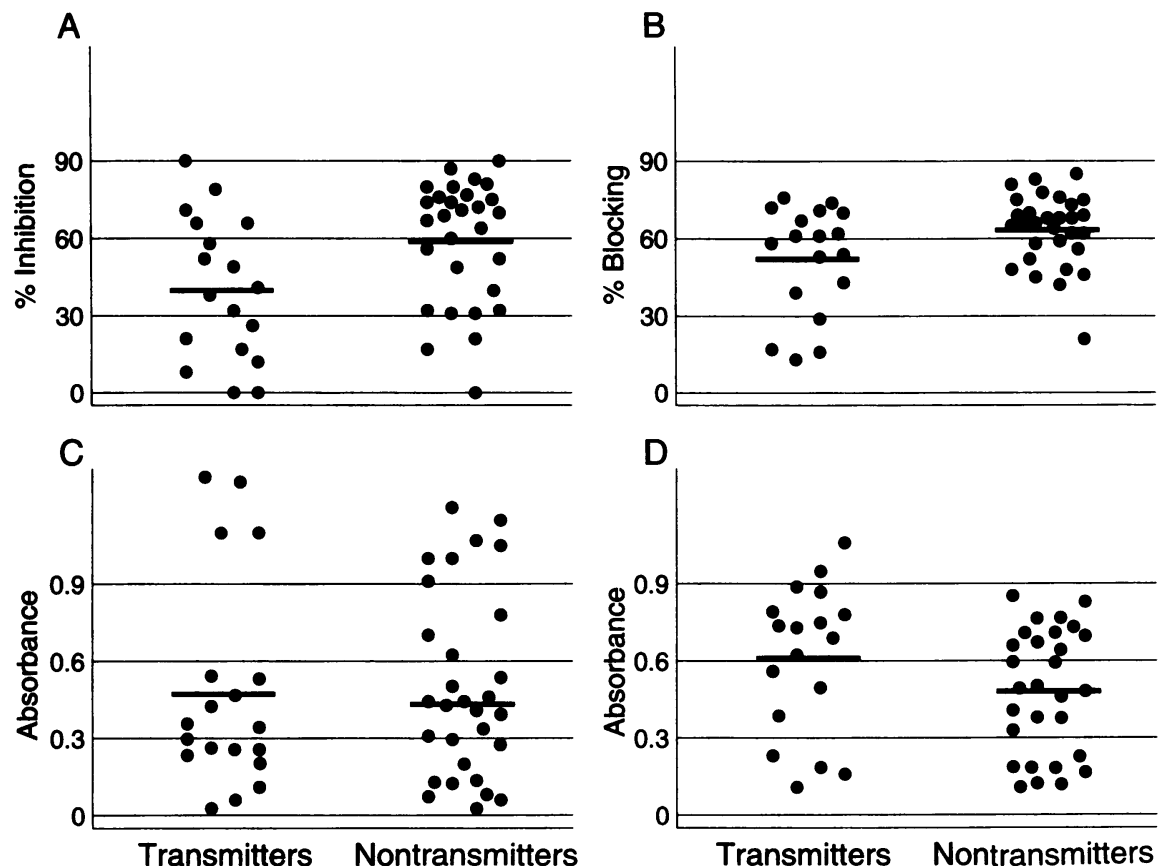

Figure 1. Results of the 4 different antibody assays performed on samples of 18 transmitting and 29 nontransmitting mothers. Each dot represents average antibody levels of one patient. A, F105 competitive inhibition assay revealed significant differences between the two groups $(P=0.024)$. $B$, sCD4 blocking assay, no significant difference was noted $(0.063)$ although a trend toward higher levels in nontransmitters was seen. $C$ and $D$, Antigp120 and anti-V3 loop assays, respectively, showed no significant differences although a trend toward lower levels was noted in nontransmitters. Bold lines represent mean values. (average of 2.2 per mother). Delivery samples were available from the majority of seropositive women (39/47). 14 patients received zidovudine treatment during pregnancy; their median $\mathrm{CD}^{+}$lymphocyte count was 273 cells $/ \mathrm{mm}^{3}$. 4 patients were transmitters and 10 were nontransmitters. For the anti-gp120, anti-V3 loop, B-F105 and sCD4 assays, plasma samples were coded and tested blindly.

Biotinylated F105 competitive inhibition assay. Percent inhibition levels of samples tested varied between 0 and $90 \%$. In the majority of women who provided multiple plasma samples, the B-F105 inhibition levels were stable throughout pregnancy. In 22 of 31 patients $(71 \%)$, the subsequent inhibition level did not vary by $>10 \%$ compared with the initial one. Inhibition levels of five women showed a decline that exceeded $15 \%$; four of those delivered HIV-1-infected babies. The inhibition level rose by $>15 \%$ during pregnancy in one nontransmitting woman.

Higher mean and median B-F105 inhibition levels were observed in the nontransmitting group (mean $59 \pm 22 \%$ SD, median 69\%) compared with the transmitting group (mean $40 \pm 29 \%$, median $40 \%$ ). The differences were significant $(P$ $=0.024$ ) (Fig. $1 A$ ). Furthermore, a greater percentage of transmitting mothers had significantly lower inhibition levels at each cumulative percent B-F105 inhibition level that was examined (Table II).

Soluble CD4 (sCD4) blocking assay. The sCD4 blocking levels for the 47 patients varied between 0 and $85 \%$ (Fig. 1 $B$ ). In 28/31 (90\%) of women who provided multiple samples during pregnancy, the subsequent blocking levels did not vary by $>10 \%$ compared with the initial sample tested, indicating that there was little change in the blocking levels during pregnancy. Nontransmitters as a group had higher blocking levels (mean 63 $\pm 14 \%$, median 66\%) compared with transmitters (mean $52 \pm 21 \%$, median $60 \%$ ) although the differences were not significant $(P=0.063)$. Analysis of data at different cumulative percent $\mathrm{SCD} 4$ blocking cutoffs did not reveal a statistically significant difference between the sCD4 blocking levels of transmitters versus nontransmitters, although a trend toward lower levels in the transmitter group was seen (Table III). There were four women with both F105 inhibition and SCD4 blocking levels below $30 \%$ and all four were transmitters.

Anti-gp120 assay. Absorbance of all samples ranged from 0.1 to 1.3 (Fig. $1 C$ ). Transmitters had higher anti-gp120 mean but lower median levels compared with nontransmitters $(0.55 \pm 0.47$ and 0.36 versus $0.47 \pm 0.36$ and 0.41 , respectively $)$. In women who provided multiple samples, there was no change in the anti-gp120 level throughout pregnancy. No significant difference was observed in the levels of transmitting versus nontransmitting mothers when analyzed at three different cumulative absorbance cutoffs (Table IV).

Anti-V3 loop assay. Absorbance of samples tested ranged from 0.1 to 1.1 (Fig. $1 D$ ). Transmitters had higher anti-V3 loop mean and median levels compared with nontransmitters

Table II. Comparison of B-F105 Inhibition Levels between Transmitters and Nontransmitters (Dilution 1:300)

\begin{tabular}{|c|c|c|c|c|}
\hline $\begin{array}{c}\text { Percent } \\
\text { inhibition of } \\
\text { B-F105 binding }\end{array}$ & $\begin{array}{c}\text { Transmitters: } \\
18 \text { patients } \\
\text { Number }(\%)\end{array}$ & $\begin{array}{c}\text { Nontransmitters: } \\
29 \text { patients } \\
\text { Number (\%) }\end{array}$ & $\begin{array}{c}\mathrm{OR} \\
(95 \% \mathrm{Cl})\end{array}$ & $\begin{array}{c}P \\
\text { values }\end{array}$ \\
\hline$<30 \%$ & $7(39 \%)$ & $3(10 \%)$ & $\begin{array}{c}5.52 \\
(1.28-23.4)\end{array}$ & $0.03 *$ \\
\hline$<50 \%$ & $11(61 \%)$ & $9(31 \%)$ & $\begin{array}{c}3.5 \\
(1.04-11.7)\end{array}$ & $0.043^{\ddagger}$ \\
\hline$<60 \%$ & $13(72 \%)$ & $11(38 \%)$ & $\begin{array}{c}4.3 \\
(1.2-14.7)\end{array}$ & $0.022^{\ddagger}$ \\
\hline$<70 \%$ & $15(83 \%)$ & $15(51 \%)$ & $\begin{array}{c}4.7 \\
(1.2-18.2)\end{array}$ & $0.03 *$ \\
\hline
\end{tabular}

Percent inhibition was calculated by measuring the ability of diluted maternal plasma to inhibit binding of the CD4 binding site antibody F105 to gp120. * Fisher exact; ${ }^{\ddagger} \chi$ square. $O R$, odds ratio; $\mathrm{Cl}$, confidence limits. 
Table III. Comparison of sCD4 Blocking Titer between

Transmitters and Nontransmitters (Dilution 1:100)

\begin{tabular}{ccccc}
\hline $\begin{array}{c}\text { Percent sCD4 } \\
\text { blocking }\end{array}$ & $\begin{array}{c}\text { Transmitters: } \\
\text { 18 patients } \\
\text { Number (\%) }\end{array}$ & $\begin{array}{c}\text { Nontransmitters: } \\
\text { 29 patients } \\
\text { Number (\%) }\end{array}$ & $\begin{array}{c}\text { OR } \\
(95 \% \mathrm{Cl})\end{array}$ & $\begin{array}{c}P \\
\text { values }\end{array}$ \\
\hline$<30 \%$ & $4(22 \%)$ & $1(3 \%)$ & $\begin{array}{c}8 \\
(0.67-407.64)\end{array}$ & $0.06^{*}$ \\
$<50 \%$ & $6(33 \%)$ & $6(21 \%)$ & $\begin{array}{c}1.92 \\
(0.41-8.87)\end{array}$ & $0.33^{\ddagger}$ \\
$<60 \%$ & $9(50 \%)$ & $9(31 \%)$ & $\begin{array}{c}2.22 \\
(0.56-8.84) \\
1.17\end{array}$ & $0.19^{\ddagger}$ \\
$<70 \%$ & $13(72 \%)$ & $20(69 \%)$ & $0.81^{\ddagger}$ \\
& & & $(0.27-5.48)$ &
\end{tabular}

Percent blocking was calculated by measuring the ability of diluted maternal plasma to inhibit binding of sCD4 to gp120. ${ }^{\ddagger} \chi$ square;

* Fisher exact. $O R$, odds ratio; $\mathrm{Cl}$, confidence limits.

( $0.56 \pm 0.3$ and 0.66 versus $0.49 \pm 0.25$ and 0.49 , respectively) These differences were not significant $(P=0.13)$. In women who provided multiple samples, there was no change in the antiV3 loop levels throughout pregnancy. No statistically significant differences were observed in the levels of transmitting versus nontransmitting mothers when analyzed at three different cumulative absorbance cutoffs (Table V).

$\mathrm{CD}^{+}$lymphocyte count. Absolute $\mathrm{CD}^{+}$lymphocyte counts at delivery were available from 12 transmitting and 22 nontransmitting women. The median $\mathrm{CD} 4{ }^{+}$lymphocyte count for the whole cohort was 430 cells $/ \mathrm{mm}^{3}$. Nontransmitter mean and median counts were 440 and 478 cells $/ \mathrm{mm}^{3}$, respectively, compared with 382 and 409 cells $/ \mathrm{mm}^{3}$ in transmitters. $2(17 \%)$ transmitters had absolute CD4 counts of $<200 \mathrm{cell} / \mathrm{mm}^{3} \mathrm{com}-$ pared with 3 of $29(14 \%)$ nontransmitters $(P=0.67) .7(58 \%)$ of transmitters and $14(64 \%)$ of nontransmitters had CD4 ${ }^{+}$ lymphocyte counts of $<500$ cells $/ \mathrm{mm}^{3}(P=0.57)$.

Immunoglobulin level. The mean and median total IgG levels for the whole cohort were 1,673 and $1,775 \mathrm{~g} / \mathrm{dl}$, respectively. The transmitter group mean and median IgG levels were 1,860 and $1,820 \mathrm{~g} / \mathrm{dl}$, respectively, compared with 1,578 and 1,490 $\mathrm{g} / \mathrm{dl}$ of nontransmitters. The IgG levels of women who had low F105 inhibition and low CD4 blocking levels $(<50 \%)$ ranged

Table IV. Comparison of Anti-gpi20 Levels between Transmitters and Nontransmitters (Dilution 1:500)

\begin{tabular}{lcccc}
\hline & $\begin{array}{c}\text { Transmitters: } \\
\text { 18 patients } \\
\text { Number (\%) }\end{array}$ & $\begin{array}{c}\text { Nontransmitters: } \\
\text { 29 patients } \\
\text { Number }(\%)\end{array}$ & $\begin{array}{c}\text { OR } \\
(95 \% \mathrm{Cl})\end{array}$ & $\begin{array}{c}P \\
\text { values }\end{array}$ \\
\hline$<0.25$ & $4(22 \%)$ & $8(28 \%)$ & 0.75 & $0.74^{*}$ \\
$<0.5$ & $12(61 \%)$ & $18(62 \%)$ & $\begin{array}{c}(0.14-3.51) \\
1.22\end{array}$ & $0.74^{\ddagger}$ \\
$<0.75$ & $14(78 \%)$ & $23(79 \%)$ & $(0.31-5.17)$ & 0.91 \\
\end{tabular}

Diluted plasma samples were added to gp120-coated plates. Bound antibodies were detected by adding labeled mouse anti-human antibodies.

* Fisher exact; ${ }^{\ddagger} \chi$ square. $O R$, odds ratio; $C l$, confidence limits.
Table V. Comparison of Anti-V3 Loop Antibody Levels between Transmitters and Nontransmitters (Dilution 1:500)

\begin{tabular}{lcccc}
\hline & $\begin{array}{c}\text { Transmitters: } \\
\text { 18 patients } \\
\text { Number (\%) }\end{array}$ & $\begin{array}{c}\text { Nontransmitters: } \\
\text { 29 patients } \\
\text { Number (\%) }\end{array}$ & $\begin{array}{c}\text { OR } \\
(95 \% \mathrm{Cl})\end{array}$ & $\begin{array}{c}P \\
\text { values }\end{array}$ \\
\hline$<0.25$ & $4(22 \%)$ & $7(24 \%)$ & $\begin{array}{c}0.9 \\
(0.16-4.36) \\
0.54\end{array}$ & $1.0^{*}$ \\
$<0.5$ & $6(33 \%)$ & $14(48 \%)$ & $0.31^{\ddagger}$ \\
$<0.75$ & $12(67 \%)$ & $24(83 \%)$ & $\begin{array}{c}0.13-2.1) \\
0.42\end{array}$ & $0.29^{*}$ \\
& & & $(0.08-2.05)$ &
\end{tabular}

Diluted plasma samples were added to plates coated with a consensus sequence of V3 loop. Bound antibodies were detected by adding labeled mouse anti-human antibodies. ${ }^{*}$ Fisher exact; ${ }^{\ddagger} \chi$ square. $O R$, odds ratio; $\mathrm{Cl}$, confidence limits

between 681 and 2,850 (mean and median of 1,436 and 1,270 $\mathrm{g} / \mathrm{dl}$, respectively) indicating that low inhibition and blocking levels were not due to hypogammaglobulinemia.

Viral culture. 15 transmitting and 20 nontransmitting women had 2 or more HIV-1 viral cultures performed during pregnancy. Of those, significantly more numbers of nontransmitters had negative cultures, suggesting lower viral load in this population (Table VI). Plasma samples for antibody analysis were available from eight of the nine women who had two or more negative cultures.

Correlation between viral culture data, CD4 binding site inhibition and blocking levels, and absolute $C D 4^{+}$lymphocyte counts. None of the eight patients who had two or more negative cultures during pregnancy had blocking and inhibition levels of $<30 \%$ as measured by either sCD4 or mAb F105 assays. The mean CD4 count for the four women with F105 inhibition and sCD4 blocking levels of $<30 \%$ was 321 cells $/ \mathrm{mm}^{3}$, lower than the mean of the whole cohort. This suggests more advanced HIV-1 disease in this subpopulation. The CD4 ${ }^{+}$lymphocyte count of women who had 2 or more negative viral cultures during pregnancy ranged between 20 and 806 cells $/ \mathrm{mm}^{3}$ (median 359).

Table VI. Comparison of the Number of Transmitting and Nontransmitting Women Who Had Negative HIV-1 Viral Cultures during Pregnancy*

\begin{tabular}{|c|c|c|c|c|}
\hline \multirow{2}{*}{$\begin{array}{l}\text { Number of } \\
\text { negative } \\
\text { cultures }\end{array}$} & \multicolumn{2}{|c|}{$\begin{array}{l}\text { Number of women } \\
\text { with negative cultures/ } \\
\text { total number of women }\end{array}$} & \multirow{2}{*}{$\begin{array}{c}\mathrm{OR} \\
(95 \% \mathrm{Cl})\end{array}$} & \multirow{2}{*}{$\begin{array}{c}P \\
\text { values }\end{array}$} \\
\hline & Transmitters & Nontransmitters & & \\
\hline $\begin{array}{l}\text { At least one } \\
\text { negative } \\
\text { culture }\end{array}$ & $\begin{array}{c}4 / 15 \\
(27 \%)\end{array}$ & $10 / 20(50 \%)$ & $\begin{array}{c}0.36 \\
(0.09-1.48)\end{array}$ & $0.12^{\ddagger}$ \\
\hline $\begin{array}{c}\text { Two or more } \\
\text { negative } \\
\text { cultures }\end{array}$ & $\begin{array}{l}1 / 15 \\
(7 \%)\end{array}$ & $8 / 20(40 \%)$ & $\begin{array}{l}0.107 \\
(0-0.79)\end{array}$ & $0.048^{\ddagger}$ \\
\hline
\end{tabular}

* Only data of women who had two or more cultures done are shown.

${ }^{\ddagger}$ Fisher exact. $\mathrm{OR}$, odds ratio; $\mathrm{Cl}$, confidence limits. 


\section{Discussion}

It is known that $15-25 \%$ of infants born to HIV-1-positive mothers become infected (27-30), but only limited data are available on what factors either allow or prevent vertical transmission to occur. One of the possible protective factors is the presence of maternal neutralizing antibodies that may reduce viral load and block cell-free transmission. Establishing a correlation between neutralizing antibody levels and transmission rate will be critically important to support the rationale for clinical trials of pregnant HIV-1-infected women with passive immunotherapy.

In this study we examined the presence of $\mathrm{CD} 4$ binding site antibodies in maternal plasma samples of women who did or did not transmit HIV-1 to their infants. A correlation was found between low inhibition levels of antibodies that overlap the F105 binding site and vertical transmission. In addition, there was a trend toward lower levels of antibodies that block CD4 binding to gp120 in transmitters compared with nontransmitters. F105 is a representative of a subset of these antibodies and binds to a discontinuous epitope that overlaps with, yet has distinct binding characteristics from, the CD4 binding site (3133 ) (see below). Furthermore, the four patients who had low levels of both F105 inhibition and sCD4 blocking were all transmitters. These findings are in agreement with recently published data that demonstrated lower rates of transmission in women whose plasma was able to neutralize autologous and heterologous HIV-1 isolates (34). All of the eight women who had two or more negative HIV-1 viral cultures during pregnancy had a F105 inhibition or CD4 blocking levels that exceeded $30 \%$, suggesting a correlation between low viral load and the presence of CD4 binding site antibodies.

One major obstacle in the development of effective passive therapy is the high rate of mutation and the antigenic variability of HIV-1 particularly for passive therapy directed against the hypervariable V3 loop. It has been shown that although neutralizing antibodies to the primary virus isolates are detectable 13-45 wk after seroconversion, escape viruses with reduced sensitivity to neutralization by autologous sera emerge rapidly (35). Patients subsequently develop neutralizing antibodies to the escape virus after a delay. Because of the rapid emergence of escape mutants, an ideal choice for passive immunotherapy would be antibodies that neutralize through binding to conserved epitopes on HIV-1. Antibodies directed against the CD4 binding site have the ability to react with and neutralize a wide range of HIV-1 isolates. Antibodies of this class are potentially able to react with and neutralize the V3 loop escape mutants since the CD4 attachment site on gp120 is thought to be highly conserved (31-33). The CD4 binding site on gp120 does not represent a single epitope but instead appears to represent an "epitope cluster" $(8,31-33)$. Both polyclonal antibodies purified from HIV-1-infected patient sera and human monoclonal antibodies derived from HIV-1-infected patient directed against this region neutralize many (but not all) laboratory and primary strains of HIV-1 (16-18, 36-39).

Recent data suggest that HIV-1 can be transmitted from mother to infant through either cell-free or cell-associated virus (40). In the work reported here, the latter pattern may explain HIV-1 vertical transmission in mothers with high levels of CD4 binding site antibodies since the presence of high titer of neutralizing antibodies may not be sufficient to prevent cell-associated transmission. On the other hand, low levels of neutralizing antibodies will likely increase the risk of cell-free transmission, a process that can potentially be reversed by passive immunotherapy. Such protection has been reported in chimpanzees that were infused with neutralizing antibodies $(41,42)$. In addition, it is possible that the higher levels of neutralizing antibodies that can be achieved through passive immunotherapy may be effective in protection. This strategy has been effective in reducing the risk of hepatitis B virus transmission from mother to newborn (43).

In summary, this study demonstrates that low levels of a subset of anti-gp120 antibodies that overlap with the F105 epitope are correlated with HIV-1 vertical transmission. The variability of CD4 binding site antibody levels in this patient population may reflect different stages of HIV-1 disease: this class of antibodies is prevalent during the asymptomatic stage, but absent both early after infection and in the later stages of disease $(11,17,19)$. Because of the complexity of factors that may affect the rate of vertical transmission, it is unlikely that passive immunotherapy alone will eliminate the risk of transmission. It may, however, reduce the probability of transmission, especially if transmission is due to cell-free virus. As the success of passive immunotherapy depends on the choice of antigenic determinants, it is essential to investigate further the role of CD4 binding site and other classes of neutralizing antibodies in this patient population.

\section{Acknowledgments}

We thank Ms. Katherine Chen, Kathleen Koury, Elizabeth Jones, Charlotte Emes, and Mr. Mark Duval for technical assistance, and Ms. Jan Welch for secretarial assistance.

This work was supported by National Institutes of Health grants AI33802, AI31783, AI26926, and Women Infant Transmission Study contract NO1 AI-82507. This work was also supported by Claudia Adams Barr Innovative Basic Science Program, a gift from the G. Harold and Leila Y. Mathers Charitable Foundation, Virus Research Institute, Sun Life of Canada, and the Million Dollar Roundtable Foundation.

\section{References}

1. HIV/AIDS Surveillance Report. October 1990. Centers for Disease Control, Atlanta, GA. 1-18.

2. Gwinn, M., M. Pappaioanou, J. R. George, W. H. Hannon, S. C. Wasser, M. A. Redus, R. Hoff, G. F. Grady, A. Willoughby, A. C. Novello, et al. 1991. Prevalence of HIV infection in childbearing women in the United States. Surveillance using newborn blood samples. JAMA (J. Am. Med. Assoc.). 265:17041708 .

3. Pitt, J., A. Landay, K. McIntosh, G. Hillyer, D. Brambilla, D. Burns, M. G. Fowler, and H. Mendez. 1992. Prenatal maternal circulating leukocyte HIV predisposes to HIV culture positivity in their infants: progress report from a North American cohort. In Program and Abstracts of the 32nd Interscience Conference on Antimicrobial Agents and Chemotherapy (Anaheim). American Society for Microbiology. 599:210a. (Abstr.)

4. European Collaborative Study. 1992. Risk factors for mother to child transmission of HIV-1. Lancet. 339:1007-1012.

5. St. Louis, M. E., M. Kamenga, C. Brown, M. Nelson, T. Manzila, V. Better, F. Behets, U. Kabagabo, R. W. Ryder, M. Oxtoby, T. C. Quinn, and W. L. Hayward. 1993. Risk for perinatal HIV-1 transmission according to maternal immunologic, virologic, and placental factors. JAMA (J. Am. Med. Assoc.). 269:2853-2859.

6. Nair, P. L. Alger, S. Hines, S. Seiden, R. Hebel, and J. P. Johnson. 1993. Maternal and neonatal characteristics associated with HIV infection in infants of seropositive women. J. Acquired Immune Defic. Syndr. 6:298-302.

7. Hutto, C., G. B. Scott, C. Mitchell, and W. Parks. 1989. Maternal risk factors for perinatal transmission of human immunodeficiency virus-1 (HIV-1). In Proceedings of the Fifth International Conference on AIDS (Montreal). 8:71a. (Abstr.)

8. Chamat, S., P. Nara, L. Berquist, A. Whalley, W. J. W. Morrow, H. Köhler, 
and C. Y. Kang. 1992. Two major groups of neutralizing anti-gp120 antibodies exist in HIV-infected individuals. J. Immunol. 149:649-654.

9. Skinner, M. A., A. J. Langlois, C. B. McDanal, J. S. McDougal, D. P. Bolognesi, and T. J. Matthews. 1988. Neutralizing antibodies to an immunodominant envelope sequence do not prevent gp120 binding to CD4. J. Virol. 62:41954200 .

10. McKeating, J., J. Gow, J. Goudsmit, L. Pearl, C. Mulder, and R. Weiss 1989. Characterization of HIV-1 neutralization escape mutants. AIDS (Phila.) 3:777-783.

11. Ugen, K., J. Goedert, J. Boyer, Y. Refaell, I. Frank, W. V. Williams, A. Willoughby, S. Landesman, H. Mendez, A. Rubinstoin, T. Kisber-Emmone, and D. B. Weiner. 1992. Vertical transmission of human immunodeficiency virus (HIV) infection: reactivity of maternal sera with glycoprotein 120 and 41 peptides from HIV type 1. J. Clin. Invest. 89:1923-1930.

12. Robertson, C. A., J. Y. Q. Mok, K. S. Froebel, P. Simmonds, S. M. Burns H. S. Marsden, and S. Graham. 1992. Maternal antibodies to gp120 V3 sequence do not correlate with protection against vertical transmission of human immunodeficiency virus. J. Infect. Dis. 166:704-709.

13. Moore, J. P., and D. D. Ho. 1993. Antibodies to discontinuous or conformationally sensitive epitopes on the gp120 glycoprotein of human immunodeficiency virus type 1 are highly prevalent in sera of infected humans. J. Virol. 67:863875 .

14. Steimer, K. S., C. J. Scandella, P. V. Skiles, and N. L. Haigwood. 1991 Neutralization of divergent HIV-1 isolates by confirmation-dependent human antibodies to gp120. Science (Wash. DC). 254:105-108.

15. Profy, A. T., P. A. Salinas, L. I. Eckler, N. M. Dunlop, P. L. Nara, and S. D. Putney. 1990. Epitopes recognized by the neutralizing antibodies of HIV 1 infected individuals. J. Immunol. 144:4641-4647.

16. Tilley, S. A., W. J. Honnen, M. E. Racho, M. Hilgartner, and A. Pinter. 1991. A human monoclonal antibody against the CD4-binding site of HIV-1 gp120 exhibits potent, broadly neutralizing activity. Res. Virol. 142:247-259.

17. Ho, D. D., J. A. McKeating, X. L. Li, T. Moudgil, E. S. Daar, N. C. Sun, and J. E. Robinson. 1991. Conformational epitope on gp120 important in CD4 binding and human immunodeficiency neutralization identified by a human monoclonal antibody. J. Virol. 65:489-493.

18. Posner, M. R., T. Hideshima, T. Cannon, M. Mukherjee, K. H. Mayer, and R. A. Byrn. 1991. An IgG human monoclonal antibody that reacts with HIV 1/gp120, inhibits virus binding to cells, and neutralizes infection. J. Immunol. 146:4325-4332.

19. Cavacini, L. A., C. L. Emes, J. Power, J. Underdahl, R. Goldstein, K. Mayer, and M. R. Posner. 1993. Loss of serum antibodies to a conformational epitope of HIV-1/gp120 identified by a human monoclonal antibody is associated with disease progression. J. Acquired Immune Defic. Syndr. 6:1093-1102.

20. McIntosh, K., J. Pitt, D. Brambilla, S. Caroll, C. Diaz, E. Handelsman, J. Moye, and K. Rich, for the National Institute of Allergy and Infectious Diseases and National Institute of Child Health and Human Development Women and Infants Transmission Study Group. 1994. Blood culture in the first six months of life for the diagnosis of vertically transmitted human immunodeficiency virus infection. J. Infect. Dis. 170:996-1000.

21. Centers for Disease Control. 1987. Classification system for human immunodeficiency virus (HIV) infection in children under 13 years of age. MMWR (Morb. Mortal. Wkly. Rep.). 36:225-236.

22. Moore, J. P., J. A. McKeating, W. A. Norton, and Q. J. Sattentau. 1991. Direct measurement of soluble CD4 binding to human immunodeficiency virus type 1 virions: gp120 dissociation and its implication for virus-cell binding and fusion reactions and their neutralization by soluble CD4. J. Virol 65:1133-1140.

23. Whicher, J. T., C. P. Price, and K. Spencer. 1982. Immunophelometric and immunoturbidimetric assays for proteins. CRC Crit. Rev. Clin. Lab. Sci. 18:213-260.

24. Landay, A., B. M. Ohlsson-Wilhelm, and J. V. Giorgi. 1990. Application of flow cytometry to the study of HIV infection. AIDS (Phila.). 4:479-497.

25. Hollinger, F. B., J. W. Bremer, L. E. Myers, J. W. M. Gold, L. McQuay, and the NIH/NIAID/ACTG Virology Laboratories. 1992. Standardization of sensitive Human Immunodeficiency Virus coculture procedures and establishment of a multicenter quality assurance program for the AIDS clinical trial group. $J$. Clin. Microbiol. 30:1787-1794.
26. Pagano, M., and K. Gauvreau. 1993. Principles of Biostatistics. Duxbury Press, Belmont, CA. p. 235.

27. Del Fraissy, J. F., S. Blanche, C. Rouzioux, and M. J. Mayaux. 1992. Perinatal HIV transmission facts and controversies. Immunodefic. Rev. 3:305327.

28. Oxtoby, M. J. 1990. Perinatally acquired human immunodeficiency virus infection. Pediatr. Infect. Dis. J. 9:609-619.

29. Ryder, R. W., W. Nsa, S. E. Hassig, F. Behets, M. Rayfield, B. Exungola, A. M. Nelson, U. Mulenda, H. Francis, K. Mwandagalirwa, et al. 1989. Perinatal transmission of the human immunodeficiency type 1 infection to infants of seropositive women in Zaire. N. Engl. J. Med. 320:1637-1642.

30. Hutto, C., W. Parks, S. Lai, M. T. Mastrucci, C. Mitchell, J. Munoz, E Trapido, I. M. Master, and G. B. Scott. 1991. A hospital-based prospective study of perinatal infection with human immunodeficiency type 1 virus. J. Pediatr 118:347-353.

31. Thali, M., U. Olshevsky, C. Furman, D. Gabuzda, M. Posner, and J. Sodroski. 1991. Characterization of a discontinuous human immunodeficiency virus type $1 \mathrm{gp} 120$ epitope recognized by a broadly reactive neutralizing human monoclonal antibody. J. Virol. 65:6188-6193.

32. Thali, M., C. Furman, D. D. Ho, J. Robinson, S. Tilley, A. Pinter, and J. Sodroski. 1992. Discontinuous, conserved neutralization epitopes overlapping the CD4-binding region of human immunodeficiency virus type $1 \mathrm{gp} 120$ envelope glycoprotein. J. Virol. 66:5635-5641.

33. Olshevsky, U., E. Helseth, C. Furman, J. Li, W. Haseltine, and J. Sodroski. 1990. Identification of individual human immunodeficiency virus type 1 gp 120 amino acids important for CD4 receptor binding. J. Virol. 64:5701-5707.

34. Scarlatti, G., J. Albert, P. Rossi, V. Hodara, P. Biraghi, L. Muggiasca and E. M. Fenyö. 1993. Mother-to-child transmission of Human Immunodeficiency Virus type 1: correlation with neutralizing antibodies against primary isolates. J. Infect. Dis. 168:207-210.

35. Arendrup, M., C. Nielsen, J.-E. S. Hansen, C. Pederson, L. Mathiesen and J. O. Nielsen. 1992. Autologous HIV-1 neutralizing antibodies: emergence of neutralization-resistant escape virus and subsequent development of escape virus neutralizing antibodies. J. Acquired Immune Defic. Syndr. 5:303-307.

36. Ho, D. D., M. G. Sarngadharan, M. S. Hirsch, R. T. Schooley, T. R. Rota R. C. Kennedy, T. C. Chanh, and V. L. Sato. 1987. Human immunodeficiency virus neutralizing antibodies recognize several conserved domains on the envelope glycoprotein. J. Virol. 61:2024-2028.

37. Steimer, K. S., C. J. Scandella, P. V. Skiles, and N. L. Haigwood. 1991 Neutralization of divergent HIV-1 isolates by conformation-dependent human antibodies to gp 120. Science (Wash. DC). 254:105-108.

38. Kang, C.-Y., P. Nara, S. Chamat, V. Caballi, T. Ryskamp, N. Haigwood R. Newman, and H. Kohler. 1991. Evidence for non-V3-specific neutralizing antibodies that interfere with gp120/CD4 binding in human immunodeficiency virus-1 infected humans. Proc. Natl. Acad. Sci. USA. 88:6171-6175.

39. Karwowska, S., M. K. Gorny, A. Buchbinder, V. Gianakakos, C. Williams, T. Fuerst, and S. Zolla-Pazner. 1992. Production of human monoclonal antibodies specific for conformational and linear non-V3 epitopes of gp 120. AIDS Res. Hum. Retroviruses. 8:1099-1106.

40. Scarlatti, G., T. Leitner, E. Halapi, J. Wahlberg, P. Marchisio, M. A Clerici-Schoeller, H. Wigzell, E. M. Fenyö, J. Albert, M. Uhlen, and P. Rossi. 1993. Comparison of variable region 3 sequences of human immunodeficiency virus type 1 from infected children with the RNA and DNA sequences of the virus populations of their mothers. Proc. Natl. Acad. Sci. USA. 90:1721-1725.

41. Prince, A. M., H. Reesink, D. Pascual, B. Horowitz, I. Hewlett, K. K Murthy, K. E. Cobb, and J. W. Eichberg. 1991. Prevention of HIV infection by passive immunization with HIV immunoglobulin. AIDS Res. Hum Retroviruses. 7:971-973

42. Emini, E. A., W. A. Schleif, J. H. Nunberg, A. J. Conley, Y. Eda, S Tokiyoshi, S. D. Putney, S. Matsushita, K. E Cobb, C. M. Jett, J. W. Eichberg and K. K. Murthy. 1992. Prevention of HIV-1 infection in chimpanzees by gp120 V3 loop domain-specific monoclonal antibody. Nature (Lond.). 355:728-730.

43. Beasley, R. P., L. Y. Hwang, C. E. Stevens, C. C. Lin, F. J. Hsieh, K. Y. Wang, T. S. Sun, and W. Szmuness. 1983. Efficacy of hepatitis B immune globulin (HBIG) for prevention of perinatal transmission of the HBV carrier state: final report of a randomized double-blind placebo-controlled trial. Hepatology. 3:135141. 